\title{
Economics
}

\section{Business Cycle Synchronization and Optimum Currency Areas: The Case of the Economic Community of West African States}

\author{
Louis Sevitenyi Nkwatoh \\ Economics Department, Yobe State University, Damturru, Nigeria
}

\section{Email address:}

sevinkwatoh@gmail.com

To cite this article:

Louis Sevitenyi Nkwatoh. Business Cycle Synchronization and Optimum Currency Areas: The Case of the Economic Community of West African States. Economics. Vol. 8, No. 2, 2019, pp. 62-72. doi: 10.11648/j.eco.20190802.14

Received: March 7, 2019; Accepted: April 22, 2019; Published: July 8, 2019

\begin{abstract}
This study analyzed the degree of business cycles' synchronization of ECOWAS economies in order to ascertain whether the formation of a broader monetary union in 2020 will be beneficial to the entire region. Annual real GDP growth rate from 1975 to 2015 was de-trended using the Hodrick-Prescott filter (HP) filter to obtain two components- permanent and transitory components. Lastly, cross country correlations of the different components were used to analyze the business cycles of ECOWAS economies. Result from the transitory component shows that the business cycles of WAEMU sub-economies are similar. But on a general note, the correlation coefficients of both components show that the business cycles of ECOWAS economies differ significantly, suggesting that, a broader monetary union involving both WAEMU and WAMZ economies will not be beneficial to the entire ECOWAS region. However, ECOWAS governments can take the risk of forming a monetary union in 2020 since a high probability of addressing a wide range of macroeconomic differentials across the region is incumbent on ex-post conditions, rather than on ex-ante prerequisite conditions that only focuses on the cost of relinquishing monetary autonomy.
\end{abstract}

Keywords: Business Cycle Synchronization, Optimum Currency Area, Endogeneity Hypothesis, Hodrick-Prescott Filter (HP), Ecowas

\section{Introduction}

The discourse on the desirability of establishing a monetary union has often been situated within the framework of the Traditional Optimum Currency Area (TOCA) theory. The theory emphasizes that the economies of candidate countries for a monetary union should be more diversified [1], open to trade [2] allow mobility of factors of production among candidate countries [2] and have similar inflation rates [4]. Technically, the cost of forming a monetary union will be less if candidate countries meet the TOCA criteria, because their response to domestic and external shocks will be similar (symmetric shocks). Symmetric shocks are therefore crucial, as they provide information on the costs and desirability of a union's monetary policy [5-7]. However, the symmetry of shocks is predicated on the similarity of industrial structures [8]. In the same vein, [9] agree that countries with different economic structures exhibit different patterns of inflation rates and therefore cannot pursue a common stabilization policy.

New Optimum Currency Areas (NOCA) theory which is an extension of the TOCA theory focuses on the potential benefits to be derived rather than the costs that will be incurred by candidate countries. Thus, candidate countries have the incentive to form a monetary union if the benefits of joining a monetary union exceed the costs [10-14]. The potential benefit of forming a monetary union is premised on the endogeneity criterion of the NTOCA theory hypothesized by [14]. It posits that business cycles of countries with close trade links tend to converge and at the same time candidate countries become more integrated after forming a monetary union. Business cycles, therefore create good preconditions for policy integration and the creation of an optimum currency area [12]. Similarly, the coordination and harmonization of the macroeconomic policies of candidate countries will be feasible and desirable if their shocks are 
symmetric and their business cycles synchronize [15] cited in [16].

The desirability to form a monetary union by the Economic Community of West African States (ECOWAS) has been persistent despite their non-actualization of a common currency on targeted dates in 2003, 20052009 and 2015. The non-actualization of the common currency on the missed targeted dates is consequent upon the level of macroeconomic convergence in the region which still remains inadequate relative to the set targets. That notwithstanding, the Central Bank Governors of ECOWAS have projected the formation of a broader monetary union between the two sub-regions-West African Economic and Monetary Union (WAEMU) and West African Monetary Zone (WAMZ) in 2020.

Noticeably, ECOWAS countries depend primarily on agriculture implying that their economic structures are similar and therefore, respond to shocks symmetrically. However, ECOWAS economies are prone to diverse exogenous and endogenous shocks due to the differentials in their major exports. For instance, Nigeria is the largest Country and the greatest oil exporter in the region, while prospective union members' international trade is heavily skewed towards commodity exports, thus making the terms of trade shocks highly uncorrelated across the region [17]. This implies that the divergence of shocks among ECOWAS economies makes the envisaged West African monetary union costly and will eventually undermine any common stabilization policy in the region.

Secondly, the business cycles of ECOWAS economies are not synchronous. The Central Bank Governor of Nigeria cited in [18] noted emphatically that ECOWAS countries' business cycles harmonization in terms of real Gross Domestic Product (GDP), inflation, broad money and interest rate have remained weak. Furthermore, the rate of expansion and contraction of the real gross domestic product (GDP) for ECOWAS economies have not been similar over the years [19].

Few studies have situated the feasibility of the West African monetary union within the framework of the TOCA theory by analyzing the degree of symmetry of shocks across ECOWAS economies. Their findings indicate that the formation of a broader monetary union will be costly [20-23]. This study therefore departs from the previous studies by analyzing the business cycles of ECOWAS economies in order to ascertain whether the formation of a broader monetary union in 2020 will be beneficial to the entire region.

The balance of this paper is structured as follows: Section 2 provides the theoretical/empirical discourse. Section 3 contains the methodology while Section 4 presents the results and analysis. The conclusion is contained in Section 5.

\section{Theoretical/Empirical Review}

\subsection{Theoretical Review}

The imperativeness to extend the Traditional Optimum
Currency Area theory (TOCA) followed the developments of the European Monetary Union in the 1990s. According to [11], the developments allowed the original optimum currency area approach to be cast in a new light. [10] tagged these new theoretical developments the "New Theory of Optimum Currency Areas". The focal point of the NTOCA reposes on the potential benefits rather than costs of forming a monetary union. Proponents of the New Optimum Currency Area theory (NOCA): [10-14, 24, 25] etc, centre their arguments on four key issues- the ineffectiveness of monetary policy, credibility of monetary policy, effectiveness of exchange rate adjustments and endogeneity of business cycles.

Basically, the TOCA theory postulates that, relinquishing monetary sovereignty is a major cost to candidate countries of a monetary union because of their inability to maintain the desired balance between inflation and unemployment. However, the Monetarist Critique, establishes that the effect of monetary policy on unemployment in the long run is neutral $[26,27]$. Hence, in the long run, policy makers can basically choose to tackle inflation rate rather than concentrate on the desired level of unemployment and economic activity [28], which therefore debunks adherents' view that the costs of losing direct control over monetary policy will be high.

A prerequisite condition for the formation of a monetary union, according to the TOCA theory is the convergence of inflation rates of candidate economies whereas, the NOCA theory emphasizes on the adoption of a credible policy by the regional Central Bank to tackle the high divergent inflation rates. The simple reason is that, a high inflation country can achieve a low inflation reputation overnight by surrendering its policy autonomy to the control of a low inflation Central Bank with no effect on the low inflation country [29] and without any loss of employment and production [10]. Therefore, candidate countries with inflation differentials will not pose any problem since they will all share the same low inflation goal [30] and can indeed provide a nominal anchor for the monetary union $[31,32]$. Summarily, inflation rate similarities are a feasible outcome from participating in a monetary union and not a necessary precondition [33].

According to the TOCA theory, the cost of losing direct control over the exchange rate instrument is significantly higher since the exchange rate can be effectively used as an adjustment mechanism to external trade imbalances. However, [34] observed that the slowness of the portfoliobalance channel causes exchange rate movements to operate with considerable lags and does not adjust instantly to external imbalances as implied by the TOCA theory. Intense debate on the ineffectiveness of the exchange as an adjustment mechanism is exemplified in the Rational Expectations theory. Based on this theory, [35] notes that perfect foresightedness of economic agents may cause changes in macroeconomic policies not to affect the current exchange rate. In the same vein, [36] submits that the effectiveness of the exchange rate as an adjustment mechanism tend to reduce, because rational firms seldom 
change their export prices in the short run, especially if they want to boost their productivity in the long run.

The TOCA theory emphasizes on certain preconditions to be met by candidate countries before they proceed to a monetary union, else they wait and improve on their status quo. Conversely, the NOCA theory enriched by [14] argues that many of the preconditions enshrined in the TOCA are in fact strengthened by the formation of a monetary union.

The business cycles of countries with close trade links tend to converge and make candidate members become more integrated after a monetary union is formed [14]. Hence, the formation of a currency area should not only be based on exante conditions, but rather emphasis should be laid on ex-post conditions that yield economic effects [37]. Studies have lent credence to the above argument by demonstrating the national business cycles of the Euro zone have further synchronized due to higher trade integration [38-41]. Macroeconomic policies become very effective in absorbing asymmetric shocks when business cycles of candidate countries are well synchronized [42].

The critiques have, however, questioned the causal relationship between trade links and correlation of member countries in monetary zone. For instance, [43] logically argues that even though the correlation of business cycles may increase with the intensity of trade links, the level of asymmetric shocks between countries may not reduce. According to [44], a currency union can increase cyclical convergence only when the symmetry in shocks and institutional structures of member countries are sufficient enough. Thus, the likelihood of wide asymmetric shocks in the long run and extra costs on the monetary union cannot be avoided. Frankel and Rose's endogeneity hypothesis generate contentions because it focuses only on trade integration and income correlation. These contentions have been moderated by incorporating aspects of endogeneity of financial integration, the endogeneity of symmetry of shocks and the endogeneity of product and labour market flexibility [45]. Also, [46] contributed in the area of endogeneity of labour market institutions, even though the endogeneity of political integration is paramount to the formation of a monetary union [47].

\subsection{Empirical Literature Review}

Historically, the analysis of business cycles and transmission of output shocks can be traced to [48] when he found positive correlations of business cycles across a group of countries. Mitchells' study forms the basis for the analysis of exchange rate regimes and business cycles relationships. [49], assessed the occurrence of European business cycles and its association with the global business cycles for 15 countries during the period before and after the creation of the European Exchange Rate Mechanism (EERM). Their finding suggests that the European business cycles among member countries are interlinked. However, the interlinked business cycles of the EERM countries and that of the United States weakened after EERM formation. In another related study, [50] concluded that the World business cycles became more group specific after 1979, with the Germany's business cycle linking countries participating in the EERM system. In a related study, [50] reaffirmed their position on a more synchronized business cycles of EERM countries with Germany's business cycle. Both studies show less synchronisation of business cycles among EERM and those outside EERM specifically U.S. The consistency of their results suggests that business cycles are more synchronized in a fixed exchange rate regime.

Basically, the traditional correlation analysis has been used to analyse business cycles' synchronisation after de-trending the annual GDP of a group of countries. [51], used the Hodrick-Prescott filter on annual GDP data for 23 European countries. They established that the mean absolute deviations of all the European countries considered had smaller amplitudes except for Luxembourg. [41] using the traditional correlation analysis, found a strong positive relationship between trade intensity and business cycle activities which supports the initial claims of $[52,53]$ that a more integrated EU had, converged business cycle activities.

Contrarily, the correlations of the cyclical components of the real GDP of Gulf Cooperation Council (GCC) countries reveal that their business cycles did not synchronize for the period 1980-2005 [54]. Similarly, [55] noticed weak business cycles' synchronization among GCC countries for the period 1980-2006. Accordingly, [56] using real GDP for the period 1970-2007 established that the business cycles of four GCC countries (Bahrain, Kuwait, Qatar and Saudi Arabia) do not synchronize. Hence, the likely benefit of a monetary union by GCC is low.

A similar approach has been used to analyze the feasibility of the East Asian monetary union. For instance, [57] estimated the cyclical dynamics of 10 East Asian countries using de-trending techniques of the output growth variable. They found evidence of synchronized business cycles for all Asian countries with the exception of Japan and China. In the same vein, a study modelled the shocks of East Asian countries using a factor augmented vector autoregressive model from 1997Q1 to 1998: Q3 [58]. Their findings indicated that the East Asian monetary union is feasible since individual gross domestic products (GDPs) of East Asian economies were synchronized in relation to the World and regional GDP shocks.

The long-term and short-term common movements among key macroeconomic variables-real GDP, intra-regional trade, private investment and consumption for seven economies in Latin America (Argentina, Brazil, Chile, Colombia, Mexico, Peru and Venezuela) for the period 1960 to 2010 was analysed by [59]. Their findings showed that economic fluctuations in these countries follow a similar pattern in terms of duration, intensity, response, and timing both in the long and short runs, implying that a monetary union was feasible for Latin America countries. Contrary studies show that the feasibility of the Latin American monetary union is unlikely. For instance, [60] examined the similarity of Argentinean's business cycle with other Latin American countries for the period 1970 to 1995 . Their results revealed 
that Argentina's real business cycle exhibited larger output volatility. However, an earlier finding by [61] suggested that the Argentinean's business cycle could be improved upon, if the economic environment were made to be more idiosyncratic. Also, the findings of [62] revealed that the business cycles for Latin American countries are weak and non-synchronous, due to asymmetry of shocks and divergences in policy responses.

There is a paucity of literature on business cycles synchronisation on various sub-Saharan African (SSA) regional blocs, perhaps due to the fact that SSA is characterised by wide macroeconomic economic differentials which makes its analysis difficult. Using cluster analysis [63] established that business cycles are more highly synchronized across the CFA France zone than across countries with sovereign currencies. In contrast, [64] tested the endogeneity of the Economic Community of Central African States (CEMAC) zone as an optimum currency area by examining the cross-country synchronization of their business cycles. His analysis concluded that the degree of synchronization of business cycles across CEMAC countries had remained low throughout the period 1960-2007, due to lower intra-regional trade and macroeconomic policies which do not converge.

In a related study using cluster analysis, [65] asserted that the Southern African Development Community (SADC) monetary union was feasible if only the Rand becomes the anchor currency for a small group of countries: Botswana, Lesotho, Namibia, South Africa, and Swaziland. A contrary result using the Triple test analysis by [66] showed a weak co-movement in the business cycles of SADAC countries from 1970 to 2010 implying that the SADAC monetary union is not feasible.

The feasibility of the East African Communities (EAC) monetary union has also been projected based on the endogeneity property of the NTOCA theory. For instance, [67] estimated a time varying parameter model for EAC economies and concluded that even though the degree of business cycle synchronization had increased since the EAC Treaty was signed in 1999, proportions of shocks across the different countries were not similar implying a weak synchronization. Hence, the EAC monetary union was not feasible. Same conclusion has been reached by [68] using the Hodrick-Prescott and the Band-Pass filters to extract information on business cycles and trends for EAC economies from 1980 to 2010. In closely related study, [69] analysed the business cycles of EAC economies alongside its major trading partner, the Euro zone. They found substantial evidence of business cycle correlation between EAC and the Euro zone nations before the adoption of the euro, with no significant increase in business cycle synchronization since the 2000 EAC Treaty upwards.

\section{Methodology}

This study explores the the Hodrick-Prescott filter (HP) by de-trending the time series variable of the growth rate of real GDPs of ECOWAS economies. This method was introduced by [70] to analyze the post-war U.S. business cycles. It has often been used to decompose a series into trend (permanent) and cyclical (transitory) components. Assume a time series of the form:

$$
y_{t}=\tau_{t}+c_{t},
$$

Where $y_{t}$ is the given time series, which is decomposed into a trend component, $\tau_{t}$ and a cyclical component, $c_{t} . t=1$, $2,3 \ldots \mathrm{T}$.

The series $y_{t}$ cannot distinguish the trend cyclical components because $\tau_{t}$ is not stochastic over time. If $\tau_{t}$ becomes stochastic and uncorrelated with $c_{t}$, then the trend component is estimated by minimizing the variance of $y_{t}$ around $\tau_{t}$ subject to a penalty that constrains the second difference of $\tau_{t}$ :

$$
\underbrace{\operatorname{Min}}_{\tau} \sum_{i=1}^{T}\left(y_{t}-\tau_{t}\right)^{2}+\mu \sum_{i=2}^{T-1}\left(\Delta \tau_{t-1}-\Delta \tau_{t}\right)^{2}
$$

The penalty parameter $\mu$ controls the smoothness of the series $\tau$. The larger the value of $\mu$, the smoother the parameter $\tau$. As $\mu \rightarrow \infty, \tau$ approaches a linear trend.

The major critic of this approach is that there are contending views on the choice of the value of $\mu$. [71] in their study found a value of 10, while [72] suggested a value of 6.25 using annual data. But [73] observed from the literature that the standard value frequently used is 100 , established by [74]. Therefore, this study adopted the frequently used value of 100 . The second contention is with the choice of the GDP variable. [76, 77] submitted that industrial production index is a better proxy for business cycles than the GDP indicator because it displays more cyclical sensitivity and can be more effective in monitoring the trend patterns. However, the industrial production index for most African countries is not readily available and thus makes the GDP variable more desirable.

The analysis is predicated on the correlations of the transitory and permanent components of the de-trended real GDP of ECOWAS economies. Positive correlations imply that business cycles synchronize and vice versa.

Alternatively, the analysis of business cycles can follow an ANOVA/Coefficient of variance tests. This approach complements the former and simply checks the equality of means and the homogeneity of the permanent and transitory components of the de-trended growth rate in real GDPs among ECOWAS countries.

Hypothesis for ECOWAS:

$\mathrm{H}_{\mathrm{o}}$ : There is no mean difference in the business cycles among ECOWAS countries.

$\mathrm{H}_{1}$ : There is a mean difference in the business cycles among ECOWAS countries. 
Table 1. ANOVA Table for a Pair of Countries.

\begin{tabular}{|c|c|c|c|c|}
\hline Source of Variation & Degree of Freedom & Sum of Squares & Mean Squares & $\mathbf{F}$ \\
\hline Between Group & 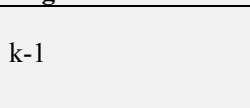 & $S_{B G}^{2}=\sum_{I}^{N} x_{i}^{2}-\frac{T^{2}}{N}$ & $\frac{S_{B G}^{2}}{k-1}$ & \\
\hline Within Group & $n-k$ & $S_{W G}^{2}=\sum_{i}^{N} \sum_{j}^{K} x_{i j}^{2}-\sum_{i}^{N} \frac{T_{i}^{2}}{n_{i}}$ & $\frac{S_{W G}^{2}}{N-1}$ & $\frac{S_{B G}^{2}}{S_{W G}^{2}}(k-1, n-k)$ \\
\hline Total & $\mathrm{n}-1$ & $S_{T}^{2}=\sum_{i} \sum_{j} x_{i j}^{2}-\sum_{i} \frac{I_{i}^{i}}{N_{i}}$ & & \\
\hline
\end{tabular}

Decision Rule:

If $\mathrm{F}_{\text {cal }}>\mathrm{F}_{\alpha}(\mathrm{n}-1, \mathrm{k}-1)$, then reject $\mathrm{H}_{0}$ implying there is a mean difference in the business cycles of ECOWAS countries.

A coefficient of variation $(\mathrm{CV})$ value less than one implies homogeneity among subgroups, whereas a $\mathrm{CV}$ value of more than 1 signifies heterogeneity among subgroups.

Annual GDP growth rates for ECOWAS countries from 1975 to 2015 were extracted from

International Financial Statistics published by the IMF and World Development Indicators published by the World Bank.

\section{Presentation and Analysis of Results}

The new optimum currency area theory emphasizes on the benefits of a currency union even though the identified shocks may be dissimilar.

Figure 1 presents the permanent and temporary components of each West Africa State's real GDP growth rate. The graphs show that all ECOWAS economies have not maintained an increasing steady growth path over the years. The permanent component shows that the growth rate of Gambia, Mali, and Senegal is not significant because the trend paths are almost revolving around zero. Among this set, the case of Mali is peculiar because it suffered from severe security and political crises (2012 coup) [78] that constrained its economic activities. The trend path between early 1990s and 1997 is positive and significant for countries like Benin, Burkina Faso, Cote D'Ivoire and Togo which may be due to devaluation exercise in the Franc zone that leveraged the economic sector. However, the negative and significant trend periods of Cote D'Ivoire are due to serious political upheavals that surged economic activities. Ghana and Niger experienced a consistent positive growth path from 1980 to 1986. Of all the economies, significant positive and negative trend effects are observed only for the case of Nigeria. The trend value is negative in 1990, positive between 2000 and 2005 and negative between 2006 and 2009 (the period of global financial crisis).
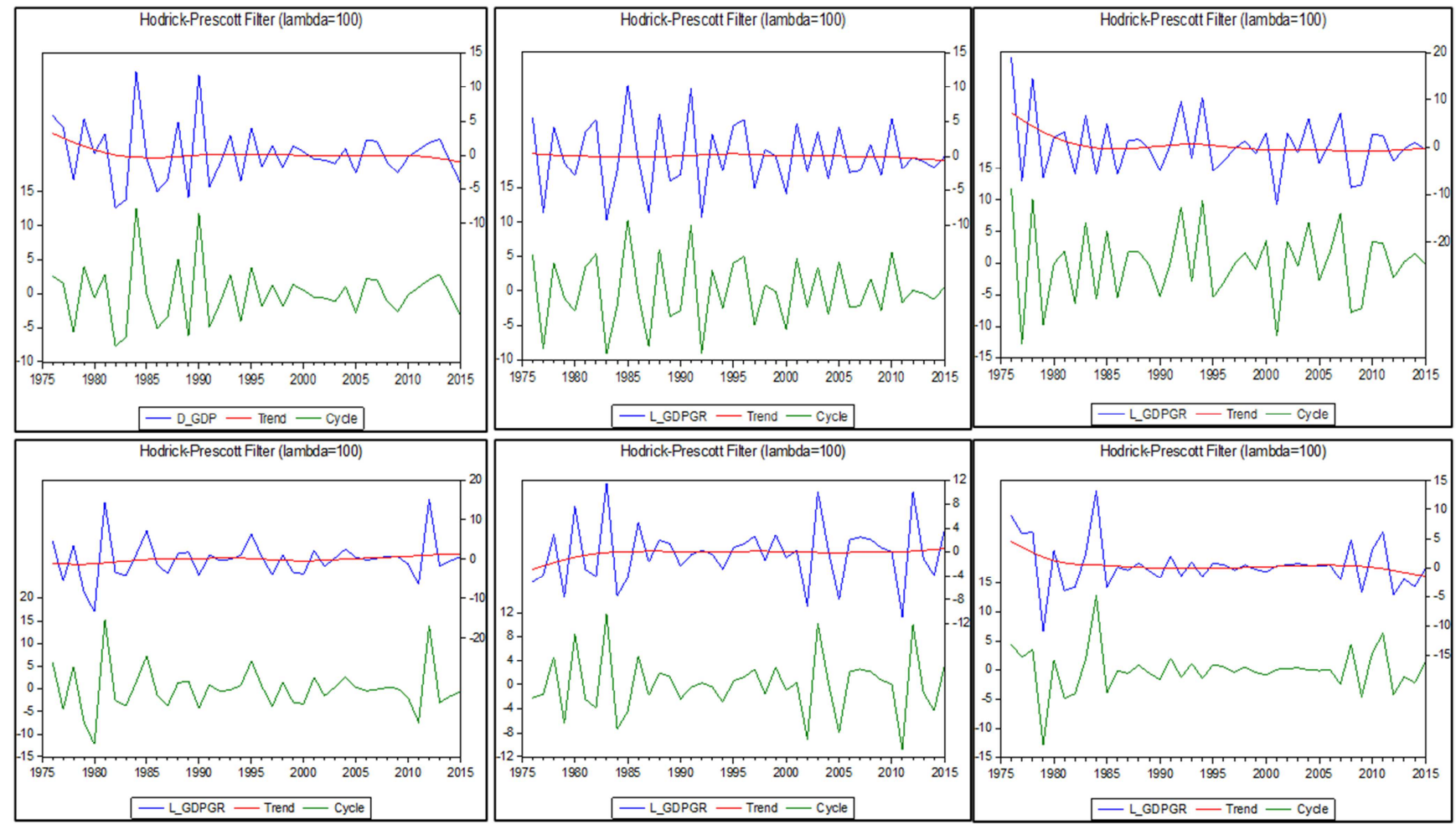

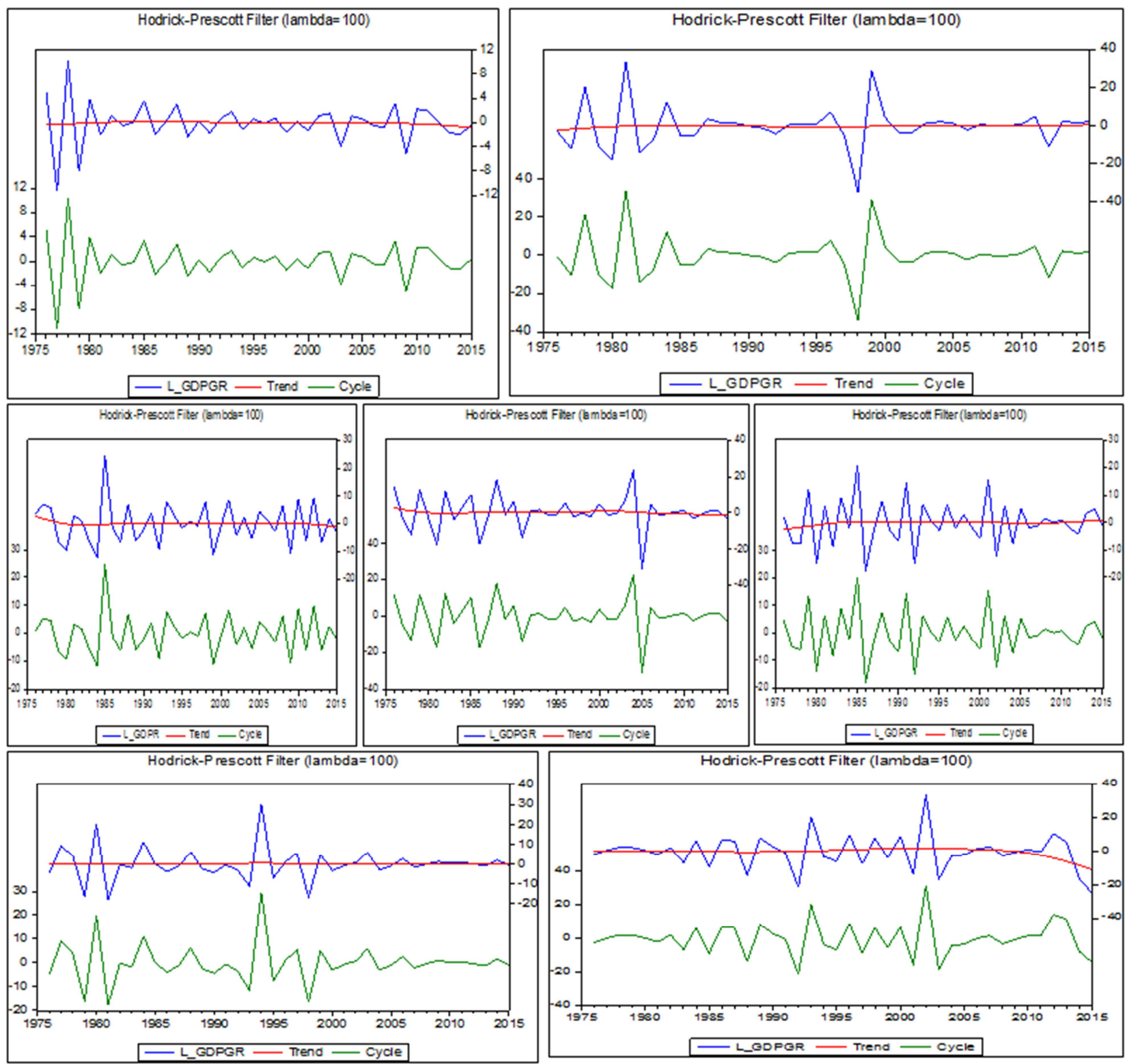

Source: International Financial Statistics.

Figure 1. Hodrich-Prescott De-trend GDP growth rate for ECOWAS Countries.

For business cycles to synchronize, their trend (permanent) and cyclical (transitory) components of the growth rate of real GDP must be correlated.

Positive and significant correlations indicate synchronization, while negative correlations suggest nonsynchronization among the cycles.

Table 2 reports the correlation coefficients of the permanent component of ECOWAS economies derived from
Hodrich- Prescott filter. The result shows that many pairs of ECOWAS economies have negative correlations, while some other pairs have positive and insignificant correlations. This indicates that the business cycles of ECOWAS economies are not synchronous (similar) and therefore, a common stabilization policy will not address the varying effects of asymmetric shocks that affect individual economies.

Table 2. Correlation Coefficients of Permanent Component of ECOWAS Economies.

\begin{tabular}{|c|c|c|c|c|c|c|c|}
\hline & BENIN & BURKINA & CAPEV & CD'VOIRE & GAMBIA & GHANA & GUINEA \\
\hline BENIN & 1 & & & & & & \\
\hline BURKINA & 0.0030 & 1.0000 & & & & & \\
\hline $\mathrm{t}$-value & 0.0168 & ----- & & & & & \\
\hline CAPEV & -0.1795 & -0.3089 & 1.0000 & & & & \\
\hline t-value & -1.0320 & -1.8370 & ----- & & & & \\
\hline CD'IVOIRE & 0.1037 & 0.4015 & -0.0264 & 1.0000 & & & \\
\hline $\mathrm{t}$-value & 0.5897 & 2.4796 & -0.1491 & ----- & & & \\
\hline
\end{tabular}




\begin{tabular}{llllllll}
\hline & BENIN & BURKINA & CAPEV & CD'VOIRE & GAMBIA & GHANA & GUINEA \\
\hline GAMBIA & -0.2150 & -0.1629 & 0.0669 & 0.0704 & 1.0000 & & \\
t-value & -1.2451 & -0.9341 & 0.3794 & 0.3991 & --- & & \\
GHANA & 0.1071 & 0.1872 & 0.1972 & -0.0571 & -0.0364 & 1.0000 & \\
t-value & 0.6092 & 1.0780 & 1.1376 & -0.3234 & -0.2060 & ---- & \\
GUINEA & 0.2162 & -0.0505 & 0.0514 & -0.2275 & -0.0259 & 0.4982 & 1.0000 \\
t-value & 1.2524 & -0.2861 & 0.2911 & -1.3218 & -0.1465 & 3.2507 & --- \\
GBISSAU & 0.3077 & 0.0704 & 0.0592 & 0.2896 & -0.1455 & -0.0308 & 0.1590 \\
t-value & 1.8296 & 0.3993 & 0.3353 & 1.7118 & -0.8317 & -0.1742 & 0.9110 \\
MALI & 0.0094 & 0.5618 & -0.1264 & 0.2810 & -0.0833 & -0.1579 & -0.2144 \\
t-value & 0.0530 & 3.8413 & -0.7210 & 1.6565 & -0.4730 & -0.9047 & -1.2415 \\
NIGER & -0.0909 & 0.7142 & -0.0097 & 0.5025 & 0.0052 & 0.3120 & -0.2177 \\
t-value & -0.5161 & 5.7718 & -0.0550 & 3.2881 & 0.0291 & 1.8574 & -1.2619 \\
NIGERIA & 0.2929 & -0.0369 & 0.1008 & -0.1239 & 0.0495 & 0.0806 & -0.1630 \\
t-value & 1.7331 & -0.2089 & 0.5729 & -0.7061 & 0.2804 & 0.4576 & -0.9348 \\
SENEGAL & 0.1929 & 0.2742 & -0.3390 & 0.4106 & -0.3092 & -0.4833 & -0.2003 \\
t-value & 1.1121 & 1.6128 & -2.0384 & 2.5475 & -1.8391 & -3.1231 & -1.1567 \\
SIERRAL & 0.0202 & -0.1029 & -0.0810 & -0.0489 & -0.2670 & -0.0332 & 0.0400 \\
t-value & 0.1142 & -0.5853 & -0.4596 & -0.2770 & -1.5675 & -0.1878 & 0.2264 \\
TOGO & -0.0528 & -0.1357 & 0.2398 & -0.3399 & 0.1734 & 0.2887 & 0.3707 \\
& -0.2993 & -0.7750 & 1.3973 & -2.0442 & 0.9959 & 1.7056 & 2.2576 \\
\hline
\end{tabular}

Correlation coefficients are in bold, while t-values are un-bold and the value of 2.0 and above indicates the significance of the coefficient at $5 \%$.

Source: Authors Computation Using Eviews 9.5

Table 3 presents the correlation coefficients of the transitory component of ECOWAS economies. The result shows that negative correlations occur among pairs of WAMZ sub-set economies, while positive correlations can be observed among WAEMU sub-set economies with the exception of Togo. This implies that the behaviour of WAEMU's business cycles is almost similar. The reason for this may be due to the already existing currency union with a common monetary policy that addresses the effect of varying asymmetric shocks in that sub- region. Hence, WAEMU countries stand the chances of benefiting from a broader monetary arrangement than WAMZ countries. However, the benefits can only be sustained if WAEMU economies can sustain coherent macroeconomic policies that will increase business cycles' synchronization across the sub-region. On the overall, most pairs of economies are not correlated implying that a broader monetary union involving both WAEMU and WAMZ economies will not be beneficial to the entire ECOWAS region.

Table 3. Correlation Coefficients of Transitory Component of ECOWAS Economies.

\begin{tabular}{|c|c|c|c|c|c|c|c|}
\hline & BENIN & BURKINA & CAPEV & CD'IVOIRE & GAMBIA & GHANA & GUINEA \\
\hline BENIN & 1 & & & & & & \\
\hline BURKINA & 0.0632 & 1 & & & & & \\
\hline t-value & 0.3581 & ----- & & & & & \\
\hline CAPEV & 0.3606 & 0.3053 & 1 & & & & \\
\hline t-value & 2.1867 & 1.8134 & ----- & & & & \\
\hline CD'IVOIRE & 0.2172 & 0.4568 & 0.0419 & 1 & & & \\
\hline t-value & 1.2581 & 2.9047 & 0.2372 & ----- & & & \\
\hline t-value & 1.5823 & -0.6854 & -2.7573 & -0.4678 & ----- & & \\
\hline GHANA & -0.495 & 0.2421 & -0.0215 & 0.5574 & 0.0006 & 1 & \\
\hline t-value & -3.2227 & 1.4114 & -0.1217 & 3.7975 & 0.0032 & ----- & \\
\hline GUINEA & 0.3598 & 0.0845 & -0.3043 & 0.458 & -0.078 & 0.6314 & 1 \\
\hline t-value & 2.1811 & 0.4794 & -1.8071 & 2.9143 & -0.4423 & 4.6061 & ----- \\
\hline GBISSAU & 0.3094 & 0.3067 & -0.0691 & 0.1353 & -0.3113 & 0.0024 & -0.02 \\
\hline t-value & 1.8406 & 1.8723 & -0.3919 & 0.7727 & -1.8533 & 0.0136 & -0.1133 \\
\hline t-value & 2.1589 & 1.1276 & -1.4923 & 3.1977 & 1.2611 & 3.7288 & 5.2868 \\
\hline NIGER & 0.1139 & 0.3256 & -0.1185 & 0.638 & -0.1269 & 0.4988 & 0.5222 \\
\hline t-value & 0.6484 & 1.948 & -0.6748 & 4.6864 & -0.724 & 3.2554 & 3.4636 \\
\hline NIGERIA & -0.2946 & 0.0181 & -0.369 & 0.0641 & 0.0476 & 0.0485 & 0.1687 \\
\hline t-value & -1.7437 & 0.1024 & -2.2457 & 0.3633 & 0.2697 & 0.2749 & 0.9684 \\
\hline SENEGAL & 0.1552 & 0.6541 & 0.2386 & 0.1252 & 0.0768 & 0.1006 & -0.1225 \\
\hline t-value & 0.8885 & 4.8913 & 1.3896 & 0.7137 & 0.4356 & 0.5718 & -0.6984 \\
\hline SIERRAL & -0.0531 & 0.0177 & -0.5298 & -0.2832 & -0.0311 & -2915 & -0.1267 \\
\hline t-value & -0.3009 & 0.1004 & -3.5337 & -16705 & -0.1761 & -1.7241 & -0.7223 \\
\hline TOGO & -0.1963 & 0.6897 & -0.2032 & 0.7457 & -0.2578 & 0.5029 & 0.3847 \\
\hline t-value & -1.1327 & 5.3881 & 1.1742 & 6.3315 & -1.5096 & 3.2913 & 2.3575 \\
\hline
\end{tabular}

Source: Author's Computation Using Eviews 9.5. 
To reaffirm the non-synchronization of ECOWAS' business cycles, the one-way ANOVA/Coefficient of Variance tests are used to check the equality of means and variances of the permanent and transitory components. If results show a significant difference in the means of the permanent and transitory components, then business cycles of ECOWAS countries differ implying they cannot proceed to a monetary union. Also, if the CV value is equal to one, then business cycles are homogenous, and heterogeneous if greater than 1 .

Table 4 shows a summary of the tests on both the permanent and transitory components of real GDP growth rates of ECOWAS economies. First, the F-test probability value of the permanent component is 0.0033 implying that the means of the permanent component of GDP growth rates differ across across ECOWAS countries. The CV value is 8.4 greater than 1, implying that the trend (permanent) paths of ECOWAS business cycles differ significantly (heterogeneous). Secondly, the F-test probability value of the transitory component is 0.9915 implying that the means of the transitory component of GDP growth rates of ECOWAS countries don't differ. However, the CV value is 1.5 closer to 1 implying a very low degree of homogeneity of the cyclical (transitory) paths of the ECOWAS business cycle. These results suggest that ECOWAS economies may benefit slightly from a broader monetary union. However, this is may be unlikely because improvements in the results may be due to the similarity of business cycles' synchronization of WAEMU economies found in the ECOWAS region. Moreover, cyclical components only produce temporal effects, while trend effects last longer. Thus, even though WAEMU countries may benefit from a broader monetary arrangement, the overall benefit for the entire ECOWAS region may not be easily achievable.

Table 4. One-way ANOVA and Coefficient of Variance Tests.

\begin{tabular}{lllll}
\hline \multirow{2}{*}{ Source of Disturbance } & \multicolumn{2}{l}{$\begin{array}{l}\text { One-way } \\
\text { ANOVA }\end{array}$} & & \multicolumn{2}{l}{$\begin{array}{l}\text { Coefficient of } \\
\text { Variance (CV) }\end{array}$} \\
\cline { 2 - 5 } & (F-test) & & \multicolumn{2}{l}{ (Levene-test) } \\
\cline { 2 - 5 } & Value & p-value & Value & p-value \\
\hline Perment Component & 2.44 & 0.0033 & 8.40 & 0.0000 \\
Transistory Component & 0.30 & 0.9915 & 1.51 & 0.3100 \\
\hline
\end{tabular}

Source: Author's Computation using Eviews 9.5.

Frankel \& Rose (1998) posit that the benefits of a monetary union can only be derived if business cycles of candidate countries synchronize due to close high trade links. The trend and cyclical components derived from HodrichPrescott (HP) filter show that the business cycles of ECOWAS economies display dissimilar patterns contrary to [14] hypothesis. [39, 40, 41] had established that the emergence of a common European cycle validates the endogeneity hypothesis. [38] inferred from the European Commission that their national business cycles further synchronize due to higher trade integration. Also, [57, 79, 59] studies revealed that high intra-regional trade link is responsible for a feasible monetary union in East Asia and
Latin America. However, the current findings of this study invalidate the endogeneity property of the NTOCA theory due to the weak inter-demand relationships among ECOWAS economies indicative of weak intra-regional trade links. Although, the permanent component of ECOWAS business cycles reveals that ECOWAS economies cannot benefit from a monetary union, the cyclical (transitory) component, however shows that WAEMU sub-set economies will benefit more if they participate in a broader monetary union. Similar results were obtained by [67] who found that the enforcement Treaty of the East African Communities (EAC) had increased the cyclical synchronization of member countries since 2000. But the cyclical similarity of WAEMU economies may be due to the pursuance of a common stabilization policy in that sub region and not necessarily trade per se. The permanent and transitory components when put side-by-side, show that the benefits of forming a broader monetary union in West Africa are unachievable.

\section{Conclusion}

This study analyzed the degree of business cycles' synchronization of ECOWAS economies in order to ascertain whether the formation of a broader monetary union in 2020 will be beneficial to the entire region. The analysis was situated within the sub-framework of the NOCA theory and used annual data from 1975 to 2015. The Hodrick-Prescott filter (HP) filter was used to de-trend the real GDP growth rate to obtain two components- permanent and transitory components. Cross country correlations of the different components were used to analyze the business cycles of ECOWAS economies. Result from the transitory component shows that the business cycles of WAEMU sub-economies are similar. But on a general note, the correlation coefficients of both components show that the business cycles of ECOWAS economies differ significantly implying that, a broader monetary union involving both WAEMU and WAMZ economies will not be beneficial to the entire ECOWAS region.

The potential benefit to be derived from the envisaged West African monetary zone by 2020 is incumbent on a strong intra-regional trade links. Therefore, ECOWAS governments need to re-enforce the already existing trade Treaties, abolish all forms of trade barriers across the region and design new policies that will strengthen regional integration. This will greatly facilitate trade activities and to a large extent, minimize the degree of divergence of macroeconomic disturbances among ECOWAS economies, hence, making their business cycles to follow a similar pattern.

Again, the formation of a monetary union should not only be based on ex-ante prerequisite conditions, but rather on expost conditions that will yield potential benefits to member countries as hypothesized by [37]. Therefore, ECOWAS governments can therefore take the risk of forming envisaged monetary union in 2020 since the implementation of a 
common stabilization policy will address a wide range of macroeconomic differentials across the region, thereby facilitating economic activities and further, strengthen regional integration.

\section{References}

[1] Mundell, R. A Theory of Optimum Currency Areas. American Economic Review. 51, 657-665 (1961).

[2] Mckinnon, R. Theory of Optimum Currency Area. American Economic Review. 53, 717-725. (1963).

[3] Kenen, P. The optimum currency area: an eclectic view, Mundell, Robert/Swoboda. Monetary Problems of the International Economy. Chicago: University of Chicago Press, 41-60, (1969).

[4] Issing, O. Economic and Monetary Union in Europe: political priority versus economic integration? Paper for the Conference 2001 of the European Society for the History of Economic Thought, February, (2001).

[5] Tsangarides, C., \& Qureshi, M. Monetary union membership in West Africa: A cluster analysis. World Development, 36, 1261-1279, (2008).

[6] Karras, G. Is Africa an Optimum Currency Area? A Comparison of Macroeconomic Costs and Benefits, Journal of African Economies. 16, 234-258 (2006).

[7] De Grauwe, P. Economics of Monetary Union, $6^{\text {th }}$ edition. Oxford University Press, (2005).

[8] Bayoumi, T., \& Ostry, J. Macroeconomic Shocks and Trade Flows within Sub-Saharan Africa: Implications for Optimum Currency Arrangements. Journal of African Economies. 6, 412-44, (1977).

[9] Jonung, L. \& Sjöholm, F. Should Finland and Sweden Form a Monetary Union? World Economy Wiley Blackwell. 22, 683700, (1999).

[10] De Grauwe, P. German Monetary Unification. European Economic Review. 36, 445-453, (1992).

[11] Tavlas, G. The New Theory of Optimum Currency Areas. World Economy. 16, 663-685, (1993).

[12] Krugman, P. Lessons of Massachusetts for EMU,'in (F. Giavazzi and F. Torres, eds.) The Transition to Economic and Monetary Union in Europe: New York: Cambridge University Press. (1993).

[13] Bayoumi, T., \& Eichengreen, B. Macroeconomic Adjustment under Bretton Woods and the Post-Breton-Woods Float: An Impulse-Response Analysis. Economic Journal. 104, 813-827. (1994).

[14] Frankel, J., \& Rose, K. The Endogeneity of the Optimum Currency Area Criteria. The Economic Journal. 108, 10091025 (1998).

[15] Fielding, D., \& Shields, K. Modelling Macroeconomic Shocks in the CFA Franc Zone. Journal of Development Economics. 66, 199-223. (2001).

[16] Njoroge, K., Opolot. J., Abuka, C. \& Okello, A. Nature and Extent of Shocks in COMESA: Implications for a Monetary
Union. Interdisciplinary Journal of Research in Business. 1, 23-46. (2011).

[17] IMF Annual Report 2007, Washington. http:/www.IMF.org/external/pub/ft/ar/2006/eng/.

[18] Uche, G. ECOWAS and Challenges of Implementing Single Currency System. The Tide Magazine. (2016). $\mathrm{http}: / /$ www.thetidenewsonline.com/2015/06/24/ecowas-andchallenges-of-implementing-single-currency-system/

[19] WAMA Statistical Bulletin 2016. http://amaowama.org/publications/statistical-bulletin.

[20] Kinful, E. Causal linkages among money, interest rate, price and output in Ghana: VECM Analysis. BOG. Working Paper, No. 05/11, Accra, July. (2005).

[21] Debrun, X., Masson, P., \& Pattillo, C. Monetary union in West Africa: Who might gain, who might lose, and why? Canadian Journal of Economics. 38, 454-481 (2005).

[22] Chuku, C. The Proposed Eco: Should West Africa Proceed With a Common Currency? Paper presented at the Centre for the Study of African Economies (CSAE) 2012 Conference on "Economic Development in Africa" Oxford University, Oxford 18-20.

[23] Ekong, C., \& Onye, K. On the Feasibility of a Common Currency in West Africa: Evidence from a Multivariate Structural VAR. Journal of Economic Theory. 4120-131 (2012).

[24] Darvas, Z. \& Szapáry, G. Business cycle synchronization in the Enlarged EU. Open Economies Review. 19, 1-19 (2008).

[25] Kwan, C. Business cycle synchronization among China and her trading partners. Hong Kong Baptist University Hong Kong, 2009.

[26] Lucas, R. Econometric policy evaluation: A critique. Reprinted in The Journal of Monetary Economics. Oxford, Basil Blackwell (1981).

[27] Friedman, M. The Case for Flexible Exchange Rates, in Friedman M. (ed.), Essays in Positive Economics, University of Chicago Press, Chicago, 157- 203 (1953).

[28] Artis, M. One Market, One Money: An Evaluation of the Potential Benefits and Costs Forming an Economic and Monetary Union. Open Economies Review. 2, 315-321 (1991).

[29] Giavazzi, F., \& Giovannini, A. Limiting Exchange Rate Flexibility: the European Monetary System, The MIT Press, Cambridge, Massachusetts, 1989.

[30] Broz, T. The Theory of Optimum Currency Areas: A Literature Review. Privredna kretanja i ekonomska politika. 104, 53 (2005).

[31] Rogoff., K. Reputation, Coordination and Monetary Policy", in Barro, R. J. (ed.) Handbook of Modern Business Cycle Theory (New York: John Wiley Press) forthcoming, 1988.

[32] Goodhart, C. Money, Information and Uncertainty. Cambridge, Massachusetts: MIT Press, 1989.

[33] Gandolfo, G. Monetary Unions in P. Newman, M. Milgate and J. Eatwell (eds.), The New Palgrave Dictionary of Money and Finance 2, Macmillan, London, 765-770 (1992). 
[34] Branson, W. Financial Market Integration and Monetary Policy in 1992. Mimeo, Princeton University and National Bureau of Economic Research, 1989.

[35] De Grauwe, P. International money: Post-war trends and theories. Oxford University Press, 1986.

[36] Krugman, P. Increasing Returns and Economic Geography. Journal of Political Economy. 99, 483-499. (1991).

[37] Frankel, J., \& Rose, A. An Estimate Of The Effect Of Common Currencies On Trade And Income. Quarterly Journal of Economics. 117, 437-466 (2002).

[38] De Grauwe, P. The Economics of Monetary Integration, Oxford University Press, Third Edition, 1997.

[39] Artis, M., \& Zhang, W. Further Evidence on the Internationa Business Cycle and the ERM: Is There a European Business Cycle? Oxford Economic Paper. 51, 120-132 (1999).

[40] Fidrmuc, J. The Endogeneity of the Optimum Currency Area Criteria, Intra-industry Trade, and EMU Enlargement. Contemporary Economic Policy. 22, 1-12 (2004).

[41] Hochreiter. E., \& Winckler, G, The advantages of tying Austria's hands: The success of the hard currency strategy. European Journal of Political Economy. 11, 83-11 (1995).

[42] Karras, G. Is Africa an optimum currency area? A Comparison of Macroeconomic Costs and Benefits. Journal of African Economics. 16, 234-58 (2007).

[43] Kenen, P. The International Financial Architecture: Old Issues and New Initiatives. International Finance. 5, 23-45 (2002).

[44] Huh, H., Kim, D., Kim, W., \& Park, S. A Factor-Augmented Vector Autoregression Analysis of Business Cycle Synchronization in East Asia and Implications for a Regional Currency Union. ADB Economics Working Paper Series, No 385, 2014.www.adb.org.

[45] De Grauwe, P., \& Mongelli, F. Endogeneities of Optimum Currency areas. December, mimeo, 2004.

[46] Blanchard, O., \& Wolfers, J. The role of shocks and institutions in the rise of European unemployment: The aggregate evidence. Economic Journal. 110, 1-33 (2000).

[47] Issing, O. Economic and Monetary Union in Europe: political priority versus economic integration? Paper for the Conference 2001 of the European Society for the History of Economic Thought, February, 2001.

[48] Mitchell, B. The impact of the Scandinavian Monetary Union on financial market integration. Financial History Review. 14, 125-148 (2007).

[49] Artis, J., Bladen-Hovell, C., \& Zhang, W. Turning points in the international business cycle: An analysis of the OECD leading indicators for the G-7 countries. OECD Economic Studies. 24, 125-165 (1995).

[50] Artis, M., \& Zhang, W. International Business Cycles and the ERM: Is ThereA European Business Cycle? International Journal of Finance and Economics. 2, 1-16 (1997).

[51] Dickerson, A., Heather, G., \& Euclid, T. Business Cycle Correspondence in the European Union. Empirica. 25, 49-75 (1998).

[52] De Grauwe, P., \&Vanhaverbeke, W. Is Europe an optimal currency area? Evidence from Regional Data. CEPR Discussion Paper no. 555, 1991.

[53] Fat'as, A. EMU: countries or regions? Lessons from the EMS experience. European Economic Review. 4, 743-751 (1997).

[54] Al-Turki, F. Essays on optimum currency area. Unpublished Ph.D Thesis, Department of Economics, University of Oregon, USA, 2007.

[55] Coury, T., \& Dave, C. Monetary Union in the GCC: A Preliminary Analysis. Working Paper Series, 08-10 (2008).

[56] Arfa, N. Gulf Cooperation Council Monetary Union: Business Cycle Synchronization, shocks correlation. International Business and Economic Research Journal. 137-166 (2012).

[57] Moneta, F., \& Rüffer, R. Business cycle synchronisation in East Asia. Journal of Asian Economics. 20, 1-12 (2009).

[58] Huh, H., Kim, D., Kim, W., \& Park, S. A Factor-Augmented Vector Autoregression Analysis of Business Cycle Synchronization in East Asia and Implications for a Regional Currency Union. ADB Economics Working Paper Series, No 385, 2014. www.adb.org.

[59] Basnet, M., \& Sharma, S. Economic Integration in Latin America. Journal of Economic Integration. 28, 551-579 (2013).

[60] Kydland, F., \& Prescott, E. Rules Rather than Discretion: The Inconsistency of Optimal Plans. Journal of Political Economy. 85, 473-491 (1977).

[61] Mendoza, E. The Terms of Trade, the Real Exchange Rate, and Economic Fluctuations. International Economic Review. 36, 101-37 (1995).

[62] Allegret, J., \& Sand-Zantman, A. Disentangling Business Cycles and Macroeconomic policy in Mercosur: AVAR and an Unobserved Components Models Approaches, 2007. https://halshs.archives-ouvertes.fr/file/index/.../JEI-Ver25mars07.do

[63] Rose, A. \& Engel, C. Currency Unions and International Integration. Journal of Money, Credit, and Banking, 34, $1067-$ 1089 (2002).

[64] Carmignani, F. Endogenous optimal currency areas: The case of the Central African Economic and Monetary Community, 2015. http://www.uq.edu.au/economics/abstract/390.pdf

[65] Buigut, S. Monetary Policy Transmission Mechanism: Implications for the Proposed East African Community (EAC) Monetary Union, 2006. http://www.csae.ox.ac.uk/.../300Buigit.pdf.

[66] Breitenbach, M., Kemegue, F. \& Zerihun, M. A Greek Wedding in SADC? Testing for Structural Symmetry towards SADC Monetary Integration. ERSA working paper 319, 2012. http://www.up.ac.za/media/shared/61/WP/working-paper319.zp39492.pdf.

[67] Kishor, K., \& Ssozi, J. Business Cycle Synchronization in the Proposed East African Monetary Union: An Unobserved Component Approach. Review of Development Economics. 15 664-675 (2011).

[68] Sheikh, A., Azam, N., Rabby, G., Alam, G., \& Khan, I. Monetary Union for the Development Process in the East African Community: Business cycle synchronization Approach. African Journal of Business Management. 5, 76327641 (2011). 
[69] Miles, W. The East African Monetary Union: Is the Level of Business Cycle Synchronization Sufficient?, 2015. http://ssrn.com/abstract $=2613628$

[70] Hodrick, R., \& Prescott, E. Post War US Business Cycles: An Empirical Investigation. Journal of Money, Credit and Banking. 24, 1-16 (1997).

[71] Baxter, M. \& King, G. Measuring Business Cycles: Approximate Band-Pass Filters For Economic Time Series. Review of Economics and Statistics. 8, 575-593 (1999).

[72] Ravn, M., \& Uhlig, H. On Adjusting the Hodrick-Prescott Filter for the Frequency of Observations. Review of Economics and Statistics. 84, 371-376 (2002).

[73] Larsson, G., \& Vasi, T. Comparison of Detrending Methods. Unpublished M.sc Thesis Submitted to Department of statistics, Uppsala University, 2012.

[74] Mohr, M. A Trend-cycle (season) Filter. Working Paper Series 499, European Central Bank, 2005.
[75] Barsky, B., \& Kilian, L. Do We Really Know that Oil Caused the Great Stagflation? A Monetary Alternative, in BS Bernanke and KS Rogoff (eds), NBER Macroeconomics Annual 2001, 16, MIT Press, Cambridge, 137-183 (2002).

[76] Artis, J., Bladen-Hovell, C., \& Zhang, W. Turning points in the international business cycle: An analysis of the OECD leading indicators for the G-7 countries. OECD Economic Studies. 24, 125-165 (1995).

[77] Camarero, M., Esteve,, V. \& Tamarit, C. Price convergence of peripheral European countries on the way to the EMU: A time series approach. Empirical Economics. 25, 149-168 (2000).

[78] Malian Economic Update (2013). The Malian Economy Holds Steady in the Face of Crisis http://www.worldbank.org/en/news/feature/2013/03/14/themalian-economy-holds-steady-in-the-face-of-crisis. 